\section{NOTES ON THE HISTORY OF THE SCIENCE MUSEUM.}

\section{II.}

I $\mathrm{N}$ the former notes I referred to the early history of the Patent Museum.

By 1874 , in consequence of the acts of the Commissioners of the $185 \mathrm{Y}$ Exhibition, land for the proper display, on the one hand, of objects chiefly illustrating art and its application to industry, and, on the other, of objects illustrating natural history, had been provided, and buildings for these purposes, as well as a School of Science, had been commenced. But for the Patent or Science Museum, no building had been erected on the five acres assigned to it by Lord Palmerston on the land bought in 1863 .

In this year the question of museums was considered by the Duke of Devonshire's Commission, and the collections at South Kensington were inquired into. The question of the Patent Museum was specially considered, and it was pointed out that objects illustrating patents should find their true place among those dealing with the advance and applications of the physical and mechanical sciences.

As a result of this inquiry, the Duke of Devonshire's Commissioners recommended to the Government the establishment of what they were the first to call a Science Museum, in which was to be included not only patented objects, but those necessary to illustrate the advances of both pure and applied science. I give the following extract from their fourth Report :-

"8I. While it is a matter of congratulation that the British Museum contains one of the finest and largest collections in existence illustrative of Biological Science, it is to be regretted that there is at present no National Collection of the Instruments used in the investigation of Mechanical, Chemical or Physical Laws, although such collections are of great importance to persons interested in the Experimental Sciences."

" $\$ 2$. We consider that the recent progress in these Sciences and the daily increasing demand for knowledge concerning them make it desirable that the National Collections should be extended in this direction, so as to meet a great scientific requirement which cannot be provided for in any other way."

"83. The defect in our collections to which we have referred is indeed already keenly felt by teachers of Science. If a teacher of any branch of Experimental Science wishes to inspect any physical instrument not in his possession, as a teacher of Literature would a book, or a teacher of Biology would a specimen, there is no place in the country where he can do it."

" 93 . We accordingly recommend the formation of a Collection of Physical and Mechanical Instruments; and we submit for consideration whether it may not be expedient that this Collection, the Collection of the Patent Museum, and that of the Scientific and Educational Department of the South Kensington Museum, should be united and placed under the authority of a Minister of State."

Here then we find the definition of a "Science Museum " as resulting from all the inquiries made by the Duke of Devonshire's Commission. Their statement regarding its organisation under a Minister of State was evidently inserted, because in another Report they pointed out the importance of the whole National Museum system being under a Minister of State, instead of being in two water-tight compartments, one of them controlled by a body of Trustees without Government responsibility.

This is too large a question to be entered upon in 1 Continued from p. 16. these notes, but it may be pointed out that if this recommendation had been acted upon the recent discussions would never have arisen.

A step was at once taken by the Government to facilitate the carrying out of these recommendations, and a loan collection of scientific apparatus was brought together in $x 876$, as an object-lesson of what such a Science Museum might be in relation to the "Patent Museum," arranged for by Lord Palmerston in 1863 , which would form part of the new museum. Still no steps were taken to commence the building.

The building of the new Natural History Museum, however, was proceeding; it was finished in 1880 . It has been shown that the land allotted for natural history purposes by Lord Palmerston was five acres. The completed museum building covered nearly four acres, and was erected in the centre of a space of about eleven and a half acres, fenced off from the remainder of the sixteen and a half acres purchased in 1863 , in such a manner as to make it difficult to apply the eight acres not built over to any other service, or even to expand largely the museum itself without injury to its architectural features. As to how this state of things, so different from that to be gathered from Lord Palmerston's speech, came about I have no information.

The recommendations of the Duke of Devonshire's Commission touching a Science Museum had much influence in leading the Commissioners of the $185 \mathrm{I}$ Exhibition to adopt proposals for the future appropriation of their estate.

Even while the loan collection of scientific apparatus in 1876 was indicating the national importance of such a museum as the Duke of Devonshire's Commission had suggested, the $18_{5}$ I Commissioners began their proposals to bring it into being by offering to endow a Science Museum with money and land. I quote from the sixth Report (p. 4r) the action taken in 1876 :-

"Influenced by these considerations, and by the regrets expressed by the Royal Commission on Scientific Instruction, in their Report already quoted, we concluded that there could be no more appropriate employment of a portion of our resources than to expend them on a building on our own Estate, for the advancement of scientific study and research, and, in connection with the South Kensington Museum, to receive the important contributions of instruments which we understood would be made to the nation at the close of the Loan Exhibition already alluded to.

"We, therefore, proposed to Her Majesty's Government that $100,000 l$. of the amount we might realise, or might be enabled to raise on ground-rents, should be devoted to the furtherance of the recommendations of the Royal Commission on Scientific Instruction by erecting, on a site opposite the Government Science Schools, a building suitable for a Museum of Scientific Instruments, or for a Library of Scientific Works, and for laboratories of scientific research and instruction. And we made this offer on condition that the Government would undertake to maintain the building, when erected, in the manner proposed. The site referred to is partly our property and partly the property of the Government, and we suggested that, in exchange for a conveyance of the part belonging to us, the Government should return to us two small portions of the site of the Exhibition of 1862 , which project into our main square."

The proposal then was very similar to the present one, utilising the land to the north of the Natural History Museum building.

Events, however, indicated that the Commission's land to the north of the plot first proposed would be a more convenient site for the Science Museum, and a second letter was addressed to the Govern- 
ment in 1878 , in which the Commission again offered to convey land and to provide $100,000 l$. for a Science Museum to be built on a plan to be approved by the Government.

The view of the Commission is thus expressed in their sixth Report (p. 44) :-

"The proposed new building would complete the group of buildings already erected by the Commission, and these... would alone satisfactorily realise the first conception of the illustrious Prince who conceived the idea of purchasing the estate. Should the Government eventually acquire also the ante-garden for the extension of the Science building now proposed, or for other public buildings, and thus connect our direct work with the Natural History and the South Kensington Museums, the success of the plans of the Prince Consort would be complete. The national collections of Mediæval and Recent Art would have their home on the portion of the Estate purchased with the funds derived from the Exhibition of $185 \mathrm{I}$ which lies on the east of Exhibition Road; the Science collections on the portion of the Estate which lies on the west of that road."

This offer was declined by the Government in 1879 on the ground of the depression of trade, and that the establishment of such a museum was not sufficiently urgent!

After this the Commissioners took no further action with regard to the Government until I888. In the meantime, however, they had granted land for the erection of the City and Guilds Institute and the Imperial Institute.

In a leiter of 1888 the land to the south of the Imperial Institute Road, reaching to the land conveyed to the Government in 1864 , was offered under the old conditions, namely, "that the land shall be permanently used for purposes connected with Science and the Arts." This plot consisted of $4 \frac{1}{2}$ acres, valued at $200,000 l$. It was offered to the Government for $70,000 l$. , and the contained southern gallery (already leased to the Government) for $30,000 l$. This offer was accepted.

In the year IgO7, in spite of the Commissioners' repeated efforts, we had no Science Museum, and the Commissioners had no more land to offer.

All that remained in 1906 was given to the governing body of the Imperial College of Science and Technology, the new institution which is to bring together all the colleges already built, and to be built, on land presented, or sold at reduced value, by the Commission for scientific purposes.

The existing buildings are the College of Science, the site of which was given gratis; the City Guilds' College, the site of which is rented at one shilling per annum; and the new Chemical and Physical Laboratories of the Imperial College, on a site sold by the Commission at less than half its value.

It may be said that, adding the value of these old plots to that of the three given in rgo6, the Commission has really endowed the new institution to the extent of some $400,000 l$.

But if a Science Museum was desirable before such a bringing together and extension of science teaching and research as the new institution affords, it is vastly more important now, when advanced research in the applications of science to the national industries is to be fostered along new lines. The opinions of those most competent to judge of the national importance of a Science Museum thirty years ago can be gathered from an appendix to the Commissioners' sixth Report (p. I3o), in which is printed the memorial addressed to the Lord President of the Council in $18 ; 6$.

Such a museum is vastly more important now, but its location at South Kensington, in close contiguity to the Imperial College, has become imperative.

No. 2I77, VOL. 87$]$
In 1907, mindful of what the Commission of the 1851 Exhibition had attempted to do during the whole time of its existence up to that time in furtherance of the completion of the National Museum organisation, I considered it my duty to call the attention of the Commissioners to the fact that practically the whole of the land belonging to them had been allocated, and that, so far, no proper provision had been made for a Museum doing for the Physical, Chemical, and Mechanical Sciences what the British Museum Library does for books, the Galleries for Antiquities, the National Gallery does for pictures, and the Natural History Museum does for the Biological Sciences.

In a memorandum to the Commissioners urging the early erection of such a museum I wrote :-

"How, then, can its early erection be brought about? I submit by holding out a special inducement to the Government to utilise in this direction some part of the land sold to the Government in I888 still waste between the old and new buildings of the College of Science and adjacent thereto.

"The importance of the eastern part of this site for the purpose I have indicated has long been recognised. In I89I it was ignorantly offered by the Government to Mr. Tate for an art gallery, but when the facts had been inquired into, the offer was withdrawn by the then Chancellor of the Exchequer, Mr. Goschen. Both in a memorial presented to Lord Salisbury and by a deputation to the Lord President of the Council and the Chancellor of the Exchequer it was pointed out that were the corner site in question not occupied by the science collections the teaching in the Royal College of Science would be cut in two when the new laboratories were erected (they have been erected since). On this ground the Government withdrew the offer to $\mathrm{Mr}$. Tate, and reserved the site for future science buildings. ${ }^{1}$

"The frontage of this plot, which indeed is the last important and considerable frontage remaining, is in Exhibition Road, stretching from the Natural History Museum grounds to the Imperial Institute Road. It lies exactly between the old and new Royal College of Science buildings.

"I may add that the frontage available in Exhibition Road is over 360 feet; that is, 60 feet longer than the west frontage of the Victoria and Albert Museum, and only i7 feet shorter than the frontage of the new buildings of the British Museum. ...

"Were this building erected, all the ground once possessed by the Commissioners along Cromwell Road and to the south end of Exhibition Road would have been utilised for the purposes of Science and Art, Art on the east side, and Science on the west side of Exhibition Ruad, as was originally planned.

"Were the southern galleries-the old Exhibition refreshment rooms-taken down, and the dangerous spirit museum removed to a safer site, such as the Natural History Museum Gardens, some distance west of the main building, there would be a space of more than four acres between the Natural History Museum and the Chemical and Physical Laboratories, and stretching from Exhibition Road to Queen's Gate, not only with the frontage to which I have referred, but another in Queen's Gate. Here, indeed, it would be possible, as a variant of the plan I have suggested, to erect a Science Museum similar to the one offered by the Commissioners to the Government in 1878 , and indicated on their plan. Much of this land is not at present permanently occupied, and the Solar Physics Observatory is under notice to quit, a new site at Caterham having already been fixed upon.

"It seems desirable that this long-standing question of a Science Museum should be again discussed, and

J Accounts of what took place will be found in NATURF, February, I3gr, and March, 1892 , vols. xliii. and xlv. 
without delay, because if any buildings are erected on the spaces referred to, any such Science Museum as the Commissioners have had in contemplation during the last thirty years, for which they have freely given their land and offered money, will be impossible of realisation, to say nothing of future extension.

"I have reason to think that if the Commissioners would again take up the question, remind the Government of their continuous action and appeal to the Government to consider the matter, such an appeal would be received sympathetically. If such an appeal could be accompanied by the renewal of the offer, already twice made, to provide a money contribution towards the building, the matter would, of course, become still more hopeful.

"The last Annual Report shows that the Commissioners have in hand funds available for such a purpose, and, speaking as a Commissioner, I can conceive no more worthy expenditure, as it will give full effect to the great purposes the Commissioners have had in view during the whole time they have been engaged in carrying out the late Prince Consort's wise advice as to the best use of their property in the nation's interest."

In I9 io the Commissioners took action in the matter. In the "Further Correspondence" already referred to [Cd. $5^{673}$ ] is given a letter (June 25, I9I0) from the Secretary :-

"The Board of Management of the Royal Commission for the Exhibition of ${ }^{8} 8_{5} \mathrm{I}$ have recently had before them a proposal to establish at South Kensington a permanent building for the accommodation of the National Science Collections. . . .

"Believing that the application to such an object of a portion of their surplus funds would be consistent with the declared policy of the Commissioners, they have resolved to recommend to the Commissioners a repetition of their former offer of $100,000 l$. towards the expense of providing a Museum, subject to their being satisfied that his Majesty's Government are prepared to make provision, so as to secure the erection of an adequate building."

On August 25, I9I0, the Treasury accepted this offer. While this correspondence was going on the Office of Works was writing to the Trustees of the British Museum with regard to the Northern Boundary, a subject dealt with in the previous notes.

We now learn from The Times report of Mr. Runciman's speech on the Education vote (July I3, I9II) that at last some compromise has been arrived at.

"Since the first announcement was made about the site of the Science Museum I have entered into negotiations with the Trustees of the British Museum, and we have now arrived at an agreement which will give us the land we require for the Science Museum and will not interfere with the development of the Natural History Museum, so that we shall have in South Kensington a group of museums which will be the envy of foreign nations." NORMAN LOCKYer.

\section{THE ROYAL COMMISSION ON TUBERCULOSIS.}

THE Reports of Royal Commissions are as a rule based almost entirely on summaries of oral evidence submitted by authorities, expert or otherwise, on the subjects with which these Commissioners have been called together to deal. Such Commissions can be expected to give little more than a résumé of what is already known.

In the Final Report of the Roval Commission on Tuberculosis (Cd. $576 \mathrm{I}$; price $6 d$.) it is soon made manifest that here something more than personal opinions of even the most eminent authorities have NO. 2177 , VOL. 87$]$ been brought together. The very genesis of the Commission made this necessary. The greatest living authority on the subject of tuberculosis, Robert Koch, had for long taught that tuberculosis was a disease common to animals and man, a disease induced by a specific micro-organism, the tubercle bacillus. Of this micro-organism there might be varieties in which the virulence or disease-producing activity might be higher in one and lower in another, but they were still essentially and specifically the same wherever they were found in the tuberculous lesions, whether of man or of animals.

At the International Congress held in London in July, I89I, Koch had turned round (perhaps not suddenly, though the announcement of the volte face had come with startling suddenness) and had announced that the tuberculous disease of cattle was not the same thing as tuberculosis of the human subject, and that the tubercle bacillus found in the tuberculosis of cattle was non-virulent for man.

The experimental work on which this statement was based was considered by many of the scientific men who heard the pronouncement to be totally inadequate to bear the wide generalisations founded upon it.

Lord Lister, the late Prof. Nocard, Prof. Bang, Sir John McFadyean, Dr. Sims Woodhead, and others were in agreement that the statement, if true, would revolutionise our whole attitude to the tuberculosis problem, and that before it could be accepted independent and corroborative evidence must be obtained.

Sanitarians in the United States appreciated the importance of this to the full, and the morning after Koch's address was given a telegram was received in London from Washington stating that the tenor of the address had been noted, and that arrangements, financial and otherwise, had been made to carry out experiments to test the trustworthiness of Koch's thesis.

Although a resolution asking the British Government to appoint a Royal Commission had been carried at the meeting of the Executive Committee, the business of the closing meeting of the Congress had been practically concluded, and no resolution asking for this Commission had been brought forward, and none could be found. One or two members of the Executive Committee, however, had carried the terms of the Resolution in their memories, they were hurriedly committed to paper, and the matter was placed before the meeting. Lord (at that time Sir James) Blyth had made a most generous offer to place a farm or farms at the disposal of any Committee or Royal Commission appointed, and it was evident that any such Commission set to work to inquire into the question would be able to carry on its investigations under most satisfactory conditions.

In these circumstances the Right Honourable Walter Long, M.P., then President of the Local Government Board, advised her Majesty Queen Victoria to appoint a Royal Commission with instructions to inquire and report with reference to tuberculosis:-

I. Whether the disease in animals and man is one and the same.

2. Whether animals and man can be reciprocally infected with it.

3. Under what conditions, if at all, the transmission of the disease from animals to man takes place, and what are the circumstances favourable and unfavourable to such transmission.

The Commission appear to have laid down a very definite plan, from which there has been no deviation. It was asked to inquire and report on the above questions. No inquiry except an actual experimental investigation seemed to give promise of any trustworthy results, and the scheme of work did not include the taking of oral evidence. 